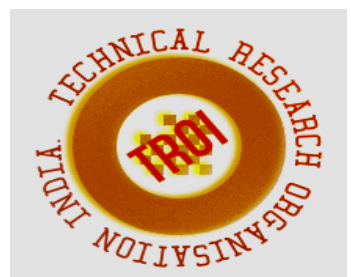

\title{
GROUNDWATER MANAGEMENT IN AND AROUND NLCIL MINES
}

\author{
${ }^{1}$ Dr. K. Ramesh, ${ }^{2}$ G. Aravind Raj, ${ }^{3}$ K. Ashok Kumar, ${ }^{4}$ V.R Janarthan, ${ }^{5}$ S.M Shiva Prakash \\ Department of Mining Engineering, Dr. TTIT, KGF, Karnataka, India. \\ 1'hod.min@drttit.edu.in, 2ggaravindvidesh5@gmail.com, 33ashokaswash@gmail.com, \\ 4jana9444701641@gmail.com, 55hivaprakash2797@gmail.com
}

\begin{abstract}
Water is one of the basic needs of the mining industry. All the operations of mining, directly or indirectly require water for their functioning. The cuddalore coastal aquifer system (neyveli coastal aquifer system) is the most productive aquifer in the Tamilnadu state as well as in the country. Continuous groundwater withdrawal for the last 5 decades for agricultural and mining activities has impact on the cuddalore aquifer system and there always exists a threat of sea water intrusion along the coast. In NLCIL mines, for mining one tonne of lignite about 13 tonnes of water has to be pumped out and large amount of water is taken, this leads to fluctuation in the water table level, for this the groundwater management should be done like artificial recharge, periodic ground water monitoring and test borehole studies to be carried out to avoid salt water intrusion and fluctuation in the water table level in and around Neyveli area.
\end{abstract}

Keywords: Geology, Hydrogeology, Lignite, Geomorphological Map, DataSatellite, Overlay, Ditches

\section{INTRODUCTION}

Water is the principal need of life on earth and an essential component for all forms of life, from micro-organisms to man. The world's water resources are under pressure and must be managed for human survival. Consumption of water has increased manifold with the growing population and rising industrial and irrigation requirements in India. The demand for potable water is increasing day by day with the enhanced living standards of mankind. The most important natural source of drinking water is from the groundwater. By assessing the groundwater potential and its quality, it can be optimally used for different purpose depending up on its availability.

Lignite is being mined at Neyveli for the last six decades by depressurizing the aquifer by pumping the groundwater for safe mining. NLCIL is operating three lignite mines (Mine-I, Mine-IA and Mine-II) through opencast mining. Mining of lignite from the Neyveli lignite field is faced with a hydrological problem due to water in the artesian aquifers below the lignite seam exerting an upward pressure which is being controlled through pumping with optimum level. The lignite occurs in the middle part of Neyveli hydrological basin consisting of semi confined; upper confined and lower confined aquifers and being mined by NLC India Limited (NLCIL). This aquifer is considered as the most important water source for drinking andirrigation. The pumped out water from mines is judicially utilized in NLCIL's industrial and township. Indiscriminate drilling of bore wells for continuous discharge of ground water for various reasons may cause problem in the management of aquifer system. Water pollution has now reached a crisis point. Almost every water body is polluted to an alarming level. The need for physio-chemical analysis of water is very vital and all sources of water must be known before consumption.

In our endeavor to meet our demands and fulfill targets, we fail to realize the impact our actions can have on the environment. We also fail to realize the proper and safe use of resources around pollution prone areas. We must adopt methods that are less prone to 
damaging the environment, in particularly the water bodies, both the nearby and the far away ones. For this purpose a complete survey of the water bodies in the mining area should be carried out to understand the challenges that need to be faced.

\subsection{Regional Geology and Hydrogeology of Neyveli}

\subsubsection{Geology}

The study area is underlined by the geological formation ranging in age from Achaean to recent. Cuddalore formation of Mio-Pliocene age consists chiefly of sandstone and extensive clay layer with the thick band of lignite seam crops out in the central part of the study area, striking NE and SW and dipping towards the SE.

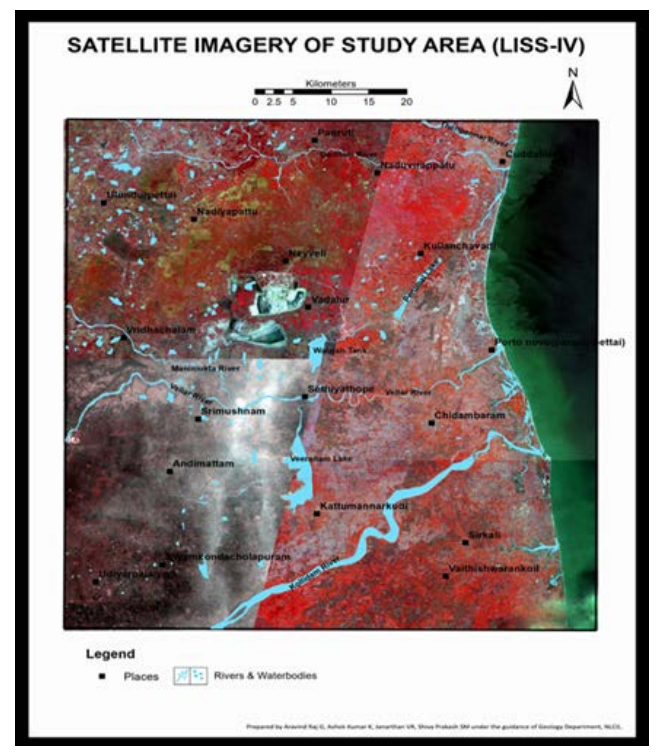

Figure 1: Satellite Imagery of Study Area(LISSIV)

\subsubsection{Lignite}

The lignite seam of the NeyveliJayamkondan area is a sub-horizontal tabular body sandwiched between an upper zone of poorly consolidated sandstone, white clay and mottled clayey sandstone and a lower zone of poorly consolidated thick sandstone (aquifer zone) with minor intercalation's of thin ash to grey shale, calcareous siltstone, sandy limestone etc. Lignite seam in general occur only as subcrop, the shallowest intersection being at $40 \mathrm{~m}$ in Neyveli area, $60 \mathrm{~m}$ in Bahur area and $50-60 \mathrm{~m}$ in Jayamkondacholapuram area below ground level. The lignite seam occurs as a curved, lensoid body with its axis of deposition swerves to NE from Neyveli east to Bahur area.

\subsubsection{Hydrogeology}

The hydrogeological setup in the area is extremely complex comprising a sequence of aquifer zones interconnected through low permeable layers. The Neyveli hydrogeological basin is a unique basin with multiple aquifers and covers an area of around 3500 sq.km. According to the classification made by NLCIL, the aquifer system in the lignite field comprises of

- Unconfined aquifer (water table aquifer)

- Semi confined aquifer (above lignite seam)

- Confined aquifer (below lignite seam).

The water table and semi confined aquifer occupies above lignite horizon whereas the confined aquifer occurs below lignite horizon. However the lignite zone acts as an aquiclude and as confining layer for the confined aquifer which is under the pressure condition.

- The unconfined aquifer occurs at the depth of about $50 \mathrm{~m}$ from the surface. The level of this aquifer fluctuates up to $15 \mathrm{~m}$ deep/high from their existence.

- The semi-confined aquifer occurred just about $90-120 \mathrm{~m}$ below the surface and can rise up to 5-10 $\mathrm{m}$ according to the season.

- The confined aquifers happened to occurred below the lignite bed. This aquifer is separated into two by a clay below the lignite bed whose thickness is between 40-50 $\mathrm{m}$ along the lignite bed.

- The aquifer between lignite bed and the clay is called upper confined aquifer and the aquifer below the clay deposit is called lower confined aquifer.

\subsection{Hydrogeological Conditions of Neyveli Basin}

The base of Cuddalore formation contains mainly of sandstone which occupies a large portion of area and has vast potential for ground water. This upper Miocene formation consists of argillaceous sandstone, pebble bearing sandstone, pebbles, sand, clay, lignite lying above the aquifer. The ground water in Cuddalore is found under confined condition, unconfined condition, and shallow, perched and deep water situations. 


\subsection{Hydrological Challenges}

Ground water pumping is a prerequisite for mining lignite in the neyveli basin. Mining of lignite posed a major problem due to the enormous hydrostatic pressure exerted at the base of the lignite seam by the underlying confined aquifers. This was first noticed during the progress of supplementary check drilling in the lignite field in November 1954, when GSI conducted simple bailer test since no submersible pumps were available at the time. This indicated at a head of $75.9 \mathrm{~m}$ of water or a pressure of $7.6 \mathrm{~kg} / \mathrm{cm}^{2}$ is acting at a base of lignite seams. This proved that any open cast excavation in the lignite deposit without controlling pressure of confined aquifer would result in rupture of the mine floor. It is important to note that NLC'S mining operation required depressurization of ground water to the extent that a Hassle frees mining operation could be maintained. The confined aquifer pressure surface is being controlled through pumping from large diameter wells (drilling: 36 inches/casing: 20 inches) strategically located at pre-determined places and taken down to depths determined from Hydrological tests. Huge submersible pumps initially of $175 \mathrm{HP}$ and later up to $250 \mathrm{HP}$ with heads of $150 \mathrm{~m}$ are now lowered and pumped at optimum discharge of around 1000GPM/well.

In order to study the hydrogeological condition in the Neyveli Lignite Field includes changes in water level, Piezometric surface, groundwater budget, hydrologic regime, aquifer characters, impact of opencast lignite mines on groundwater quality, hydro geochemical behaviours major ions and trace elements in groundwater, possibility of sea water intrusion and other environmental aspects in response to depressurization of Neyveli Artesian Basin, mining and associated industrial activities. Since last four and half decades, massive opencast mining and large scale depressurization of upper confined aquifer as well as associated industrial activities such as the pit head thermal power plants, urea plant, briquetting and carbonization plant and clay washing plant, couple with increasing agricultural and domestic demand of groundwater year after year may also disturb the natural dynamics of Neyveli Groundwater Basin.
- A huge reservoir occurs below the lignite bed, exerting an upward pressure of 6 to 8 $\mathrm{kg} / \mathrm{cm}^{2}$.Unless the water pressure is reduced the mining operation cannot be taken safely.

- For controlling the ground water pressure high efficiency pumps are used at capacity of 500 GPM and 1000 GPM pumps in pumping wells.

- Wherein early periods, 50000 GPM water has been pumped out. But, in recent times it is reduced up to 32000 GPM.

- For Mining 1 tons of lignite about 13 tons of water has to be pumped out.

- High ratio overburden to lignite(ie.,11 ton:1ton )

- Wherein ground water control, seepage water and storm water is also been controlled. Where for controlling seepage water pontoons are used.

- Currently about 60,000 GPM of ground water alone is pumped out in all three mines put together to excavate 24 MT/annum. Whereas the same quantity of water was pumped for mining 3.5 MT/annum in early days.

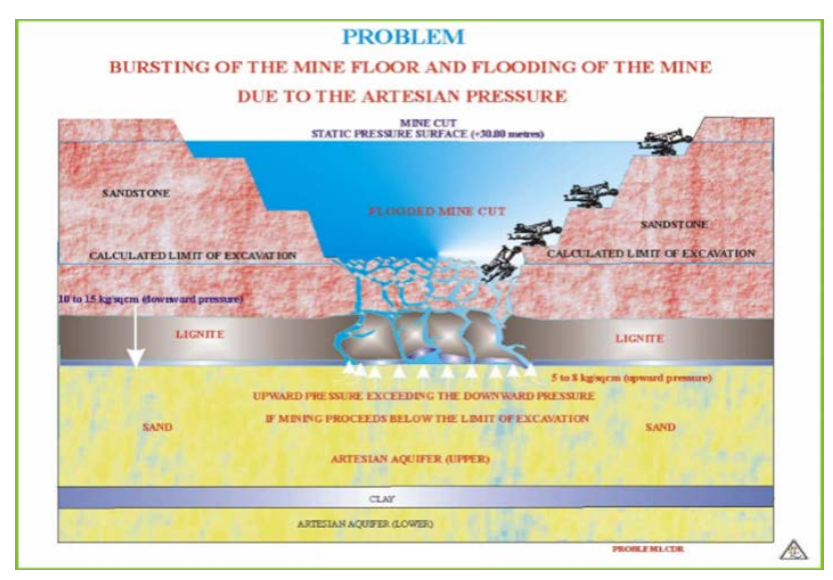

Figure 2: hydrological challenges in NLCIL mine

\section{NEED FOR GROUND WATER EXTRACTION IN VARIOUS UNITS 2.1 Groundwater Extraction From Mines}

Mining of lignite from the Neyveli lignite field is faced with a stupendous hydrological problem due to water in the artesian aquifers below the lignite seam exerting an upward pressure which if not controlled could 
jeopardize the mining operations. The hydrological investigations and a series of pumping tests conducted in this field proved that the practical-cum economic solution to depressurize the aquifer and maintaining the pressure head constantly could be done by large scale pumping operations from a series of pumping wells situated at hydrologically calculated distance from the lignite mining excavation zone.

\subsubsection{Water requirement for Thermal Power Plants}

The total power production capacity of NLCIL is 3090 MW at present, which requires huge quantity of water for boilers and disposal etc. Since the Neyveli Township has population of more than 1.5 Lakhs sufficient quantity of water need to be provided for (dwellings) residents.

\subsubsection{Utilization Of Pumped Out Mine Water}

NLCIL is pumping about 279560 Kiloliters per day of ground water from its mines for safe mining operations, which is entirely consumed for Thermal Power Stations requirements. The drinking water requirement of 44500 Kiloliters / day in Neyveli Township is met from treated storm water from Mine-II.

In Mines, the storm water and seepage water collected during rainy season is pumped out on an average to the tune of 26500 GPM, of which 6800 GPM is consumed for drinking water use after treatment. 19700 gpm of storm water is being let out into Sengalodai, kanyaodai, and paravanar feeding to Walaja tank and Perumal eri. by which 20000 acres of land is cultivated by local farmers. However, NLCIL has plans for treatment for all storm water in future as a step towards ground water conservation.

\subsection{Need For Ground Water ManagementSystem}

As could be seen, certain quantity of water has to be continuously pumped out for the safe mining operation and at the same time the water requirement for industries and township have to be fulfilled. The regional impact of continuous pumping has to be studied in detail in order to plan the ground water extraction for mining operations as well as to meet the water requirement for industries andtownship.

Therefore a water balance which is a must has to be worked out and an effective ground water management system has to be evolved in order to safe guard the entire region from ground water point of view.

Groundwater fluctuation in and around NLCIL

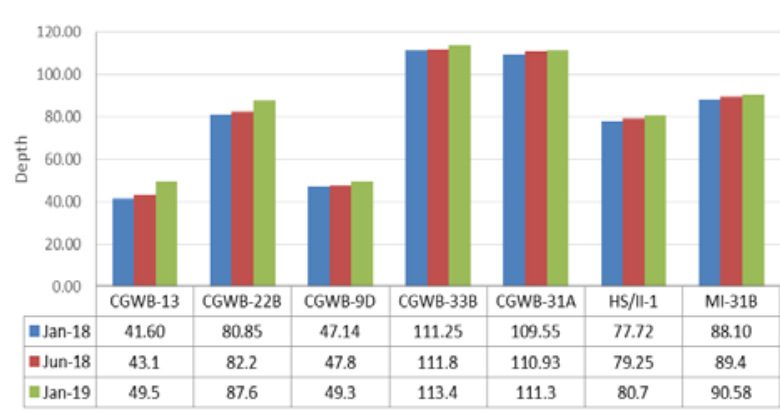

Figure 3: Groundwater Fluctuation

\subsection{Geological Data}

\subsubsection{Geological Map}

The Geological map of the study area in parts of Neyveli Sedimentary Basin was prepared from the Satellite Imagery (IRS-LISS IV). The study area contains Ariyalur formation (Cretaceous), Cuddalore formation (Tertiary), Tiruchirapalli formation and also Alluvium formation (Quaternary) \& Migmatites

\subsubsection{Geomorphological Map}

Geomorphology is the study of landforms. The landforms are an important input for identification of potential zones of groundwater occurrence. Four satellite imagery have been used for the preparation of geomorphological map of the area.The various landforms delineated from imagery are described below. They are
1. Pediments
2. Pediplain
3. Channel Fills

\subsubsection{DRAINAGE MAP}

The drainage map of the study area was prepared from the Survey of India (SOI) Toposheets through the latest information extracted from imagery. The study area was mostly covered by the dendritic drainage pattern and Rectangular drainage pattern. The Rectangular drainage patterns are noticed in South East part of study area and dendritic drainage patterns are noticed in Northern part.The drainages were digitized on the basis 
of pattern from the elements of interpretation. The dendritic pattern mostly occurs on flat lying sedimentary bed rocks.

\subsubsection{Introduction}

\section{GIS - STUDY}

ArcGIS is a geographic information system(GIS) for working with maps and geographic information. It is used for creating and using maps, compiling geographic data, analyzing mapped information, sharing and discovering geographic information, using maps and geographic information in the range of applications, and managing geographic information in database.

\subsubsection{Digitizing}

Digitization of the collected maps involves encoding the map features as $\mathrm{X}$ and $\mathrm{Y}$ coordinates in digital form. Digitization was done by the help of satellite imagery of study area. Lines are traced to define their shape. A digitizer button, pressed periodically along the line records $\mathrm{X}$ and $\mathrm{Y}$ coordinated digitized line is a series of $\mathrm{X}$ and $\mathrm{Y}$ coordinates.

\subsubsection{Editing}

This is used to correct the errors, modification of the geographical data set or the tabular data file containing the attribute data. The various errors includes dangle errors, overshoot, undershoot, label errors etc.

\subsubsection{Map Joining}

Digitization of drainage patterns, major roads and highways, Pediments, Pedi plains and Channel fill zones are Completed. After this we have to join the maps and give them as a single map. The edge matching process ensures that arcs and polygon boundaries match across borders.

\subsubsection{Overlay}

This involves the merging of different layers which were created. The different layers are water level maps for dug wells and tube wells, Geomorphology map and geological map. This analysis gives an idea to achieve our project aim.

\subsection{DataSatellite}

The satellite data used for this study is CARTOSAT-1.The specifications of the satellite data used in this study are listed below

\begin{tabular}{|c|c|}
\hline \multicolumn{2}{|c|}{ Table 1 - Details of the Satellite Data } \\
\hline Satellite Product & $\begin{array}{c}\text { Resource Sat \& } \\
\text { Cartosat-1 }\end{array}$ \\
\hline Sensor System & $\begin{array}{c}\text { LISS-IV + } \\
\text { Panchromatic }\end{array}$ \\
\hline Types of Images & $\begin{array}{c}\text { False Color } \\
\text { Composite (FCC of } 3 \\
\text { bands) }\end{array}$ \\
\hline Projection & $\begin{array}{c}\text { UTM (Universal } \\
\text { Transverse Mercator - } \\
\text { Zone 44N) }\end{array}$ \\
\hline Datum & WGS 1984 \\
\hline
\end{tabular}

\subsubsection{Preparation of Integrated Map Showing}

\section{Artificial Recharge Structures}

The artificial recharge location are decided mainly by dug wells water level contour maps and also the overlying layers of geological contacts, geomorphological features like pediments, Pediplain and channel fills.

In case of drainage layer we can find the third order stream to identify the potential zones and suggest the effective recharge methods for sustainable development and management of ground water resources in and around Neyveli sedimentary basin.

By integrating different layers such as drainage, geomorphology and geology gives a way to identify the potential zones for suggesting artificial recharge methods. As a result of this integrated analysis we can get $\mathbf{3 0}$ potential areas.

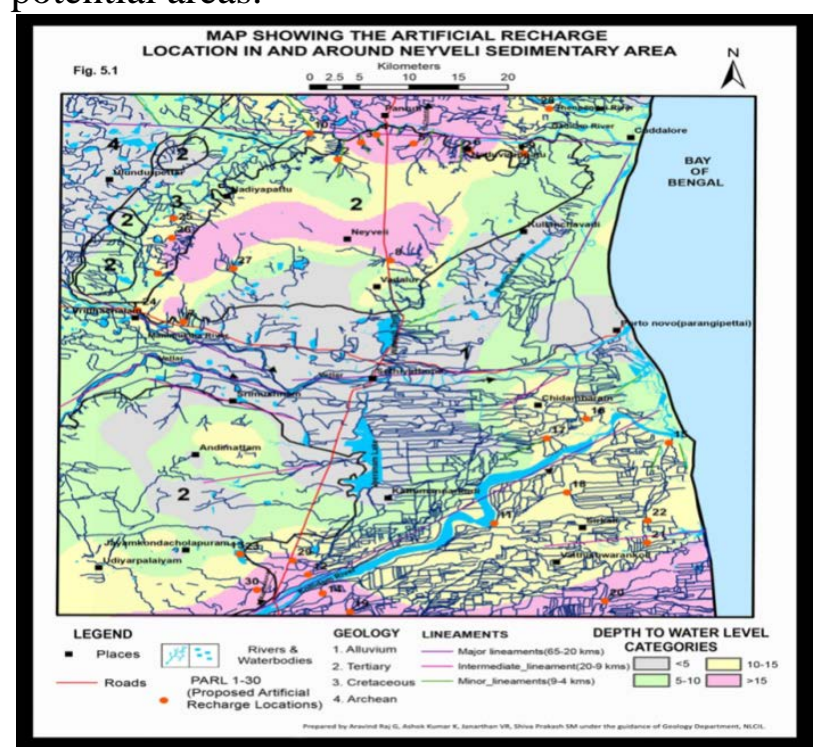

Figure 3: 30 Effective Recharge Zones in and Around Neyveli Sedimentary Basin 


\subsection{Effective Recharge Methods\&Artificial recharge methods}

As result of the growing competition for water there is increased attention to the use of artificial recharge to augment ground water supplies. Artificial recharge is a process by which excess surface water is directed into the ground either by spreading on the surface, by using recharge wells or by altering natural conditions to increase infiltration to recharge an aquifer. It is a way to store water underground in times of water surplus to meet demand in times of shortage. Water recovered from recharge projects can be used for landscape irrigation and many other uses. Artificial recharge can also be used to control seawater intrusion in coastal aquifers.

The different artificial recharge structures that are commonly used in different parts of the world.

- Spread basins

- Recharge pits and Shafts

- Ditches

- Recharge Wells

- Subsurface Dams

- Check Dams

\section{- Spreading Basins}

This method involves surface spreading of water in basins that are excavated in the existing terrain. Highly permeable soils are suitable for effective artificial recharge. In case of direct discharge, the amount of water entering the aquifer depends on

- Infiltration rate

- Percolation rate

- Horizontal water movement capacity

This method most effective where there are no low permeable layers between the land surface and aquifer and clear water is recharged. Suspended sediments in recharge water results in clogging is the common problem in this method.

\section{- Recharge Pits And Shafts}

Recharge pits and shafts could be effective as it penetrates the less permeable strata in order to recharge the dewatered aquifer whereas conditions that permits surface spreading methods for artificial recharge are rare. To increase the rate of recharge, the side slopes of the pits increased. In order to sustain high recharge rates recharge, pits requires maintenance since the unfiltered runoff water leaves a thin film of sediment on the sides and bottom of the pits.

Shafts may be circular, rectangular, or of square cross-section and may be backfilled with porous material. Due to the accumulation of fine grained materials, recharge rates in both shafts and pits may decrease with time.

\section{- Ditches}

Ditches are long narrow trench, with its bottom width less than its depth. Ditch system is designed according to the geological condition that exists at given site. The ditches could terminate in a collection ditch designed to carry away the water that does not infiltrate in order to avoid ponding and to reduce the accumulation of fine material.

\section{- Recharge Wells}

Recharge wells are used to recharge water into deeper water-bearing zones directly. Recharge wells are suitable in area where a thick impervious layer exist between the surface of the soil and the aquifer to be replenished.

They are also suitable where land is scarce. By this method, relatively high rate of recharge is attained. Clogging of the well screen or aquifer may lead to excessive build-up of water levels in the recharge well.

\section{- Subsurface Dams}

Groundwater moves from higher pressure head to lower one. This will help in semiarid zone regions especially in upper reaches where the groundwater velocity is high. By exploiting more groundwater in upper reaches more surface water can be utilized indirectly thereby reducing inflow into low reaches of supply. Groundwater is stored either in natural aquifer materials in subsurface dams or artificial sand storage dam.

\section{- Check Dams}

Check dams are small barriers built across the direction of the water flow on shallow river and streams. The small dams retain 
excess water flow during monsoon rains in a small catchment area behind the structure.

\subsection{Advantages Of Artificial Recharge}

- The use of aquifers for storage and distribution of water and removal of contaminants by natural cleaning processes which occur as polluted rain and surface water the soil and percolate down through the various geological formations.

- In rock formations with high, structural integrity few additional materials may be required to construct the wells.

- When demand is high, artificial ground water recharge stores water during the wet season and for use in the dry season.

- Aquifer water can be improved by recharging with high quality injected water.

- It increases the sustainable yield of an aquifer.

- Control of surface water runoff to provide aquifer recharge reduces sedimentation problems in many river basin.

\section{CONCLUSION}

- The integration of Geological, Geomorphological, Drainage and Water level contour data are found to be an immense help in demarcating high potential location for artificial recharge in the study area.

- 30 High potential locations in the study area can be recharged through the check dams and percolation wells. The potential areas belongs to Cuddalore formation (Tertiary era) the area is rich in pediments source with Cuddalore sandstone which is Favourable for infiltration.

- The 30 high potential locations has mostly commendable source from $3^{\text {rd }}$ order stream, the rivers and lakes, so we suggest that the construction of check dams along with percolation well as a combined structure and percolation well in the natural local lakes in a series with the distance of approximately 500m between each of them would increase the water level.
- By the method of distillation, the pond areas are extended and that in turn increases the Ground water level. Also the Percolation wells are constructed at the distillation area that has to recharge and increase Piezometric level.

The periodical monitoring of water level for the past 3 years shows fluctuation in Ground water level which is due to pumping of ground water at mining areas in NLCIL and insufficient recharge due to erratic rainfall. Taking into consideration of above factors, a few artificial recharge structures such as check dams sand percolation wells are suggested for the replenishment of high potential locations.

\section{REFERENCES}

[1] Pathak V and Banerjee A K, 1992, "Mine water pollution in Chapha Incline, Umaria Coalfield, eastern Madhya Pradesh, India”, Mine water and the environment, Vol. 11, pp: 27-36

[2] Ramakrishnaiah C.R and Ranganna G., 2008, "Hydrochemical analysis and evaluation of groundwater quality in Tumkur Taluk, Karnataka state, India”, Int J Environ Res Public Health, Vol-5(3), pp: 158-164.

[3] Ghose M.K and Sen P.K, 1999, "Impact on Surface Water Quality due to the Disposal of Tailings from Iron Ore Mines in India”, Journal of Scientific \&Industrial Research, Vol-58, September 1999, pp: 699-704

[4] Zakir H M, Islam M M, Arafat M Y and Sharmin S, 2013, "Hydrogeochemsitry and quality assessment of waters of an Open coal mine area in a developing country”, International Journal of Geosciences Research, Vol. 1, pp: 20-44

[5] Singh R N, Atkins A K and Pathan A G, 2010, "Determination of ground water quality associated with lignite mining in arid climate”, International Journal of Mining \& Environmental Issues, Vol. 1,pp: 65-78

[6] Carlos V M, Pompeo M L M, Lobo F L, 2011, "Impact of coal mining on water quality of three artificial lakes in Morozini River Basin”, ActdLimnologicaBratsiliensid, Vol. 23, pp: 271-281 
[7] Bishnoi, M. and Malik, R., 2008 “Ground water quality in environmentally degraded localities of Panipat city, India”, Journal of Environmental Biology. Volume 29, No.6, pp. 881-886.

[8] S. P. Gorde et al, Nov-Dec. 2013, “Assessment of Water Quality Parameters", International Journal of Engineering Research and Applications Vol. 3, Issue 6, pp.2029-2035.

[9] Dr. S.Mohan Department of Civil Engineering, IIT Madras, May 2000. Report on "Geographic Information System (GIS) based regional Micro level hydrological model for assessment of ground water recharge in Neyveli basin".

[10] Dr. S. Vasudevan Department of Earth Sciences, Annamalai University, Chidambaram, Tamil Nadu. Report on "Study of Land use Land cover and Hydro Geomorphology through Satellite Imageries for NLC Mining Lease area, Neyveli”

[11] Dr.T.Kannadasan Department of Geology, Bangalore University, Bangalore, 2003. Report on "Use of Aeromagnetic and Satellite data for Geological Interpretation and Identification of Potential Ground Water Zones - A case study from North Arcot District, Tamil Nadu”. 